\title{
OS PRIMEIROS PASSOS DA REVISTA EDUCAÇÃO \& SOCIEDADE
}

\author{
Eloisa de Mattos Höfling ${ }^{1}$
}

\section{Introdução}

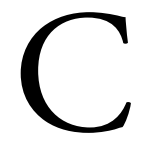

om orgulho recebi o convite dos editores da Educação \& Sociedade, a mim dirigido como "Estimada sócia fundadora do CEDES e da Revista E\& S", para participar da publicação comemorativa dos 40 anos da Revista, com "um artigo, como acertado anteriormente, mais coloquial".

E é com uma mistura de sentimentos que tentarei dar conta dessa pequena grande tarefa. Assustada com o passar do tempo (40 anos!!!), orgulhosa por ter participado desse importante trabalho, privilegiada por ter vivido momentos fundamentais na construção da história da educação brasileira ao lado de colegas e amigos essenciais.

E já registro, de início, o impiedoso vazio afetivo da ausência da Beth Pompeo - professora Elizabeth de Almeida Silvares Pompeo de Camargo —, companheira inseparável também nesta história, e a impossibilidade de recorrer a sua meticulosa memória para me ajudar nessa reconstrução. É impossível falar do surgimento da Revista, da criação do CEDES, sem me lembrar dessa incansável profissional que, sempre em parceria com a Ivany — professora Ivany Rodrigues Pino - , foram e são o que costumo designar como a "alma” do CEDES.

Decidi caminhar pela memória, propriamente dita, caminho que me permite o registro baseado nas lembranças, nas impressóes, num compromisso maior com os momentos vividos e menor com a descrição objetiva dos fatos, não desprezando o compromisso com a realidade.

Falar dos primeiros passos da Revista nos remete à década de 1970 na sociedade brasileira e à Faculdade de Educação da Universidade Estadual de Campinas (UNICAMP). Eram tempos sombrios, de arbitrariedades, de cerceamento

\footnotetext{
${ }^{1}$ Universidade Estadual de Campinas, Faculdade de Educação - Campinas (SP), Brasil.

E-mail: elohofling@yahoo.com.br

DOI: 10.1590/ES0101-73302018191028
} 
de posições discordantes da palavra instituída oficialmente. As primeiras reunióes para a discussão e criação da Revista aconteceram em 1978. A educação, como outros campos do conhecimento, demandava discussóes e análises mais amplas, e estávamos começando a respirar um pouco nesse país, com perspectivas de reorganização da sociedade. Apesar de limitada, a Anistia veio em 1979; aconteceram as greves de trabalhadores em 1979 e 1980, a fundação de um Partido de oposição, enfim movimentos sociais vários surgiam ocupando o cenário nacional.

E nós, do campo da Educação, ancorados nas Ciências Sociais, sentíamos necessidade de ter um veículo, uma publicação que refletisse esse momento difícil e complexo da sociedade, nos movendo no espaço crítico de reflexão e investigação do objeto educação e de suas relações com as diversas esferas da sociedade. No interior da Faculdade de Educação da UNICAMP nós, inicialmente um pequeno grupo de docentes, convidamos todos para uma primeira reunião para pensar nessa possibilidade, porque entendíamos que fazia parte de nosso trabalho intelectual, não nos limitando a nossas pesquisas e publicações próprias. Era o investimento em um trabalho coletivo, para além de nosso contrato funcional com a Universidade.

Pensando hoje, entendo que o sentimento de urgência quanto à intervenção nos rumos da política educacional, as incertezas e também possibilidades daquele momento histórico nos impulsionavam em direção a uma organicidade que nos fazia presentes em associaçôes, congressos, seminários, lançamentos de revistas, praticamente em tudo que contribuísse para a análise daquele momento e para ampliar os horizontes da democracia.

Colegas dos diversos departamentos aderiram à proposta, e o primeiro Comitê de Redação da E\&̛S foi composto por Moacir Gadotti, Mauricio Tragtemberg, Elizabeth Pompeo de Camargo e Antonio Muniz de Resende (EDUCAÇÃO \& SOCIEDADE, 1978).

Diversos documentos e catálogos de memória, publicados e disponíveis no site do CEDES, relatam minuciosamente as composiçóes dos Comitês ao longo do tempo, a quem interessar.

Lembro-me bem de colegas experientes na vida universitária, como Mauricio Tragtemberg, Milton José de Almeida, Evaldo Amaro Vieira - suportes constantes e essenciais ao CEDES - nos alertando para o perigo de uma publicação institucional e o risco de endogenia que poderia trazer se não ampliássemos nossos horizontes. Ainda bem que o fizemos sempre, insistentemente, com a segura direção da Beth e da Ivany.

A fundação do Centro de Estudos Educação e Sociedade (CEDES), em 1979, veio na direção de assegurar e consolidar a autonomia da Revista e outras publicaçóes, e a garantia de traçar seus rumos respeitando seus objetivos, desde seu surgimento. 
Em sua longa trajetória no acidentado caminho do mercado editorial no Brasil, especialmente o de publicações científicas, a $E \mho \Im S$ enfrentou obstáculos de diferentes naturezas, sem nunca transigir em seus princípios e em seu compromisso com o pensamento crítico em relação à educaçáo. Dificuldades com editoras, distribuiçáa, financiamento foram arduamente superadas pela Direção do CEDES e seus Comitês Editoriais, mantendo a todo custo a autonomia de sua produção intelectual.

A Revista conquistou um lugar de grande reconhecimento, respeito pelos critérios adotados em seu trabalho e permanência no campo editorial das Ciências da Educação, fazendo jus a importantes celebraçôes de seus 40 anos!

Deliberadamente, não mencionarei colegas valiosos que, após o período de implantação da Revista e do CEDES, foram se incorporando e continuam com seu trabalho em diferentes frentes na difícil tarefa de manter vivos um espaço e veículo de tamanha importância!

Minha modesta homenagem a todos os que fizeram e fazem a história da E\&S... vida longa à Revista Educação \& Sociedade e ao CEDES!

\section{Referência}

EDUCAÇÃO \& SOCIEDADE, Campinas, ano 1, n. 1, set. 1978. 